原

レバミゾールを用いた胃癌免疫化学療法の効果

一術後 4 年生存率について一

岡山大学医学部第 1 外科

三 輪 恕 昭

胃癌例84例にレパミゾール(LMS)を150mg/日連続 3 日間で隔週每に手術 3 日前より

投与開始し, 136例の historical control 群の生存率之比較した. 尚, 両群共に MF 化学 療法を併用した。その結果, LMS は対照群に比して胃癌全例に有意な延命をもたらし，

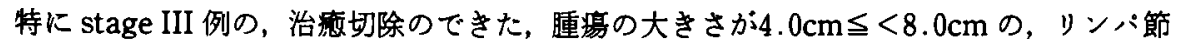
転移が $\mathrm{n}_{1}$, 深達度かi se で, $\mathrm{v}_{0}, \mathrm{l}_{1}$ の症例に有意な延命をもたらした。

臬引用語： levamisole, gastric cancer

はじめに

非特異的免疫賦活郕を用いる免疫療法はすでに一般 化され, host-mediated な免疫能增強が抗尰煌, 廷命に つながることは明らかとなりつつある。

最近 biological response modifier (BRM) の概念 がとり入れられ，免疫療法剤の範囲が大巾に広げられ， レパミソール1(LMS)を含む従来の免度賦活昘の評価 もすでに確立されたものになりつつある。しかし，一 般的には免度賦活剛への評価はまだ一定したすのでな く，免疫賦活剂の投与法，投与量，投与期間，抗癌剂 との併用の問題等，まだまだ検討されるべき項目は多 ()$^{2}$.

我々は数年来 LMS の基礎的, 臨床的検討を行って きたが(3)-5), 今回胃癌例についての術後 4 年生存率が 分かったので，その延命効果について報告したい．

\section{対象と方法}

昭和50年 4 月より55年 3 月までに，岡大第 1 外科に 入院して手術をうけた症例のうち82例にLMSを投与 した. 対象は historical control で昭和46年 4 月より 50 年 3 月までに同しく当科に入院,手術をらけた136例で あった（表 1)。これらのらち stage III 例では対照群， LMS 群の背景因子の間に差はみられなかった（表 2). LMS は 1 日 $150 \mathrm{mg}$ の分 3 投与を 3 日間連続して 11日休薬するといら投与法（3投11休）を手術 3 日前 上り開始し，目標を 2 年間として可能な限り内服させ た。併用化学療法は mitomycin C (MMC) を術後 1 週目より $4 \mathrm{mg} \times 2 /$ 週で計 $40 \mathrm{mg} て ゙, F T \cdot 207 は$ $600 \sim 800 \mathrm{mg} /$ 日を,これる可能な限り継続内服させた。
表 1 对象胃病例

\begin{tabular}{c|c|c|c|r}
\hline \multicolumn{2}{c|}{ 胃痁 stage } & 対 照群 & LMS 群 & 計 \\
\hline stage & I & 35 & 26 & 61 例 \\
& II & 17 & 7 & 24 \\
& III & 32 & 32 & 64 \\
& IV & 52 & 19 & 71 \\
計 & & 136 & 84 & 220 \\
\hline
\end{tabular}

LMS : levamisole

表 2 背景因子(胃癌 stage III)

\begin{tabular}{|c|c|c|c|c|c|}
\hline & 項 & 目 & 対照群 & LMS 群 & $\mathrm{t}$ 榆定 \\
\hline 例 & 数 & & 32 & 32 & \multirow{20}{*}{$\begin{array}{l}\text { 有意差 } \\
\text { な し }\end{array}$} \\
\hline 切 除 自 & 度 & 治密切除 & 28 & 26 & \\
\hline & & 非治雭切除 & 4 & 6 & \\
\hline \multirow{3}{*}{\multicolumn{2}{|c|}{ 睡瑒の大きさ }} & $<4.0 \mathrm{~cm}$ & 4 & 7 & \\
\hline & & $<8.0 \mathrm{~cm}$ & 13 & 18 & \\
\hline & & $\geqq 8.0 \mathrm{~cm}$ & 15 & 7 & \\
\hline 源 達 & 度 & ssp & 3 & 2 & \\
\hline & & se & 23 & 28 & \\
\hline リン ハ 算 & 節 & $\mathrm{n}_{0}$ & 6 & 8 & \\
\hline \multirow[t]{2}{*}{ 転 } & 移 & $\mathrm{n}_{1}$ & 10 & 13 & \\
\hline & & $\mathrm{n}_{2}$ & 16 & 11 & \\
\hline \multirow[t]{3}{*}{ 静脈侵 } & 表 & $\mathrm{v}_{0}$ & 23 & 19 & \\
\hline & & $v_{1}$ & 5 & 11 & \\
\hline & & $\mathrm{v}_{2}$ & 4 & 1 & \\
\hline \multirow{6}{*}{\multicolumn{2}{|c|}{ リンバ管侵粠 }} & 不明 & 0 & 1 & \\
\hline & & $l y_{0}$ & 7 & 7 . & \\
\hline & & $1 y_{1}$ & 6 & 10 & \\
\hline & & $l y_{2}$ & 15 & 9 & \\
\hline & & $1 y_{8}$ & 4 & 5 & \\
\hline & & 不明 & 0 & 1 & \\
\hline
\end{tabular}

LMS : levamisole 
また両群の治療法の間にはほとんど差がなかった。胃 癌進行度等に関しては胃癌取り扱い規約によっだ!。

尚, 生存率は累積生存率で表わし, 有意差検定は Student t-test, Cox·Mantel 法によった。

\section{成 鈢}

\section{1. 胃癌全例での成繶}

対象群, LMS 群全例の術後 4 年までの成績は图 1 に示した. LMS 群の生存率は常に対照群より高く、そ の狅は有意であった $(p<0.05)$.

これらを stage 別に stage Iから IV をでに分けて 表わしたのが図 2 である. stage I 例では LMS 群の生 存率は対照群よりむしろ低く, stage II 例では LMS 群 の生存率の方が高かったが症例数が少なく, stage IV 例では対照群と LMS 群の生存率に差はなく，ともに LMS の生存率上年奻果はなかったが, stage III 例で はLMS 群の生存率が対照群のそれより有意に高く (p<0.05)，LMSの延命奻果がみられた。

\section{2. 胃癌 stage III 例での成榠}

すでに記した如く, stage III 例では対照群と LMS 群の背景因子の間に差がなかった。またこの stage III 例でのみ LMSによる生存率上昇効果がみられた。 そこで更に stage III 例のらちで種々の項目について 対照群と LMS 群の生存率について検討した。

a. 切除度と生存率

胃癌 stage III 例を治痽切除例と非治虑切除例に分 けて LMSの効果をみた。

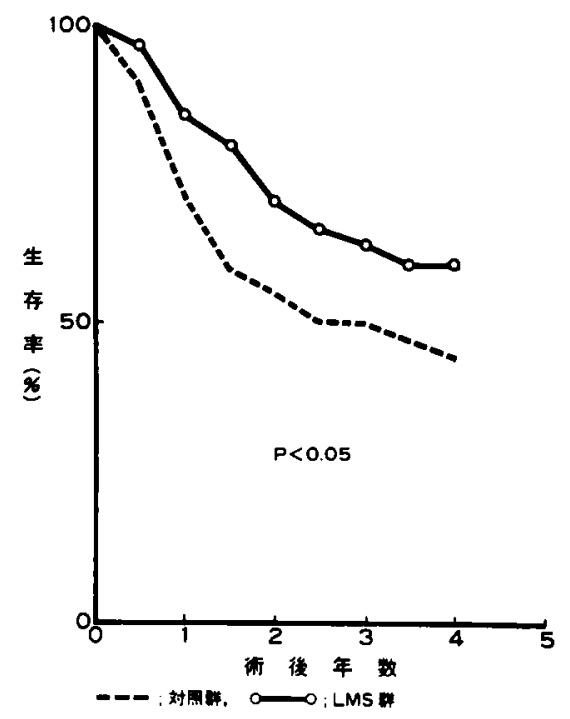

图 1 男盘例に対する levamisole $の$ 延命奻果 (全例)

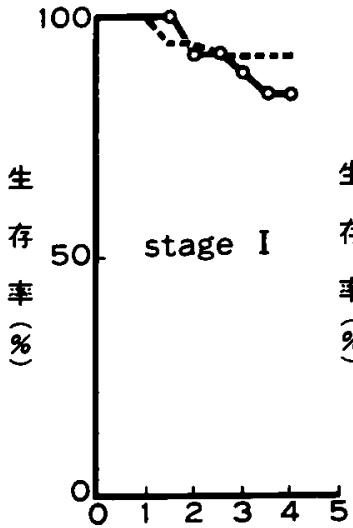

術後年数

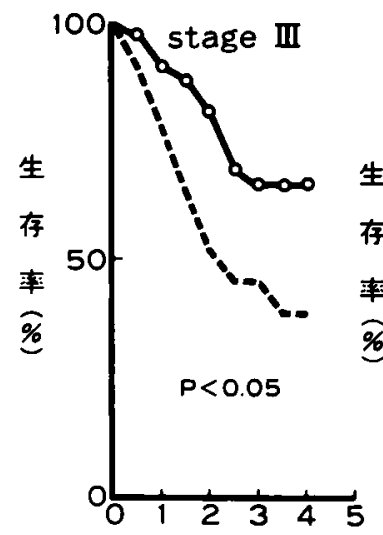

術後年 数

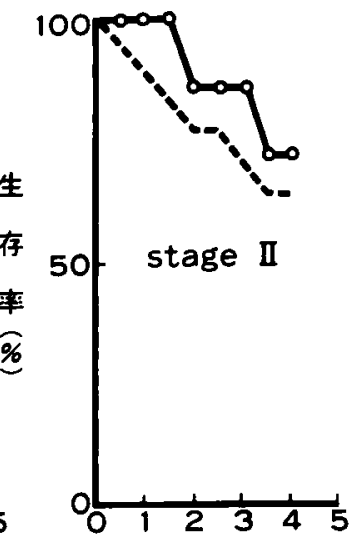

術後年 数

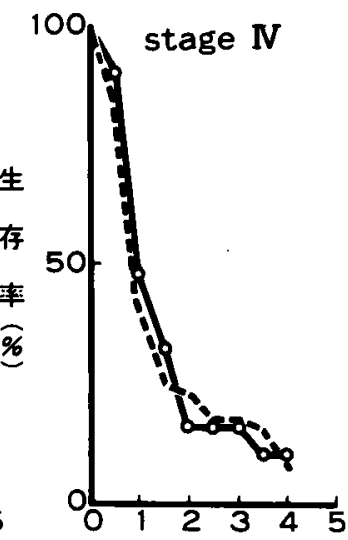

術後年数

$$
\text { - - ; 对照群， ○：LMS 群 }
$$

図 2 胃福例の stage 別生存率
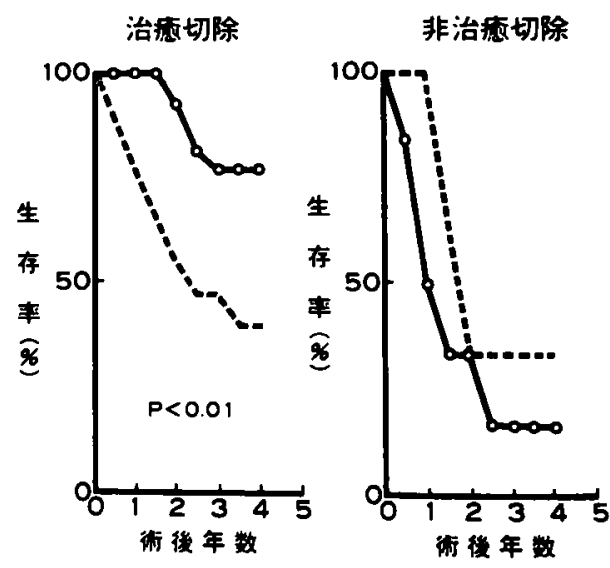

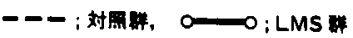

图 3 切除度と生存窑 (stage III) 


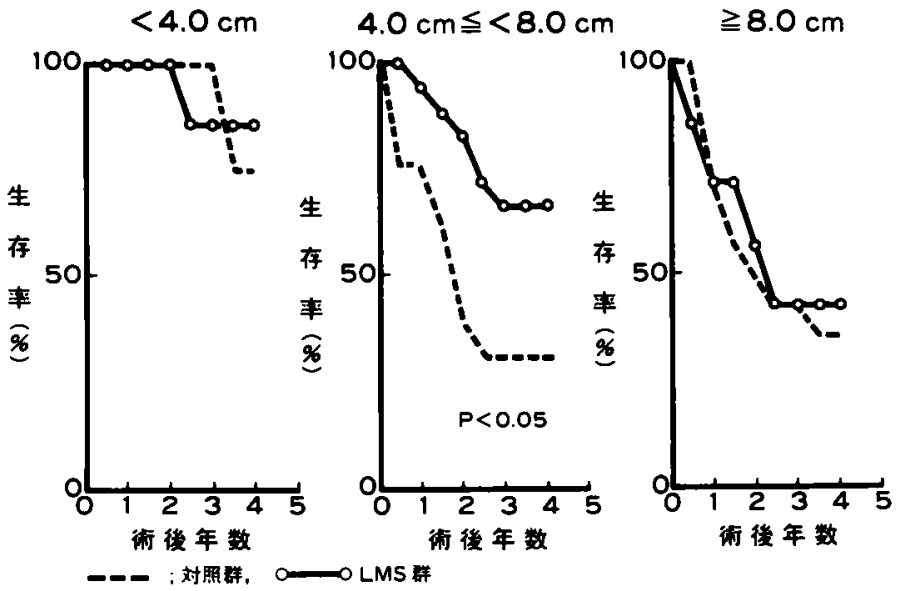

図4腫䞍径と生存率（stage III）

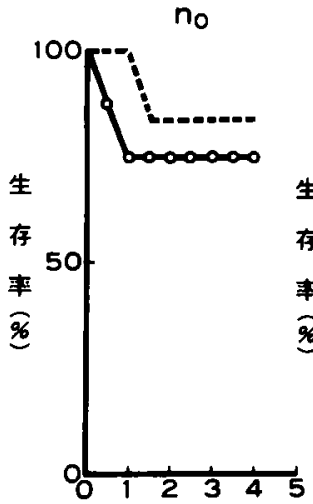

術後年数

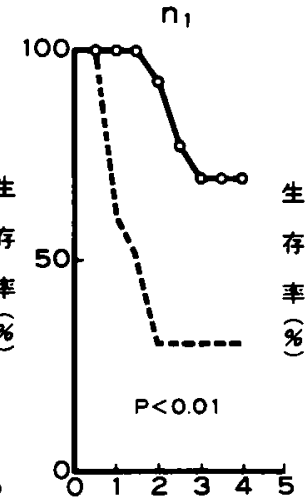

術挠年数

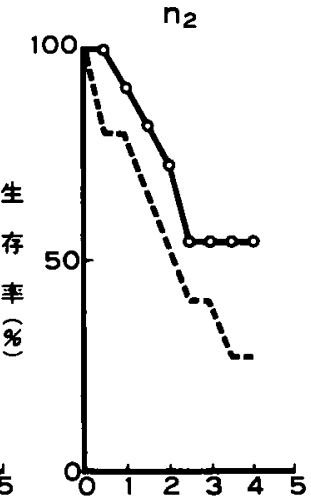

街後年数

図 5 リンパ節転移と生存率（stage III）

图 3 左の如く, 治癒切除例では LMS 群の生存率は 有意に対照群の生存率より高かった。しかし非治瘾切 除例では, LMS 群の生存率はむしろ対照群の生存率 より低かった。

b. 腫汪の大きさと生存率

次に胃癌の大きさ別にLMSの効果をみた。胃癌の 大きさ区分は三輪ら”の方法により，4.0 $\mathrm{cm}, 8.0 \mathrm{~cm}$ を 境とした。

対照群と LMS 群の生存率の差は胃癌の大きさが中 等度の大きさの $4.0 \mathrm{~cm} \leqq<8.0 \mathrm{~cm} の$ 例にみられた $(\mathrm{p}<0.05)$ (图 4 ).

c.リン八゙節転移と生存率

LMS の延命効果をリンバ節転移度別にみた， $\mathrm{n}_{0}$ の 症例ではむしろ対照群の生存率の方が高く, $\mathrm{n}_{2}$ 例では
LMS 群の生存率の方が高かったが有意差はなく， $\mathrm{n}_{1}$ 例でのみ LMS 群のア存率の方が対照群の生存率より 有意に高く $(\mathrm{p}<0.01)$ ，LMSによる延命がみられた (图 5 ).

d. 深達度と生存率

胃癌の壁深達度と LMS の延命効果については图 6 に示した、注とんどの症例が se 例で占められており， その se 例では LMS 群の生存率が対照群のそれより 有意に高かった $(\mathrm{p}<0.05)$ (図6).

e. 脈管侵褧と生存率

脈管侵襲は静脈侵襲とリンハ管侵襲について LMS の効果をみた。

静脈侵俥別ではLMS の生存率は $\mathrm{v}_{0}$ 例で有意比対 照群の生存率より高く $(\mathrm{p}<0.01)$ (図 7 ), リンパ管侵 


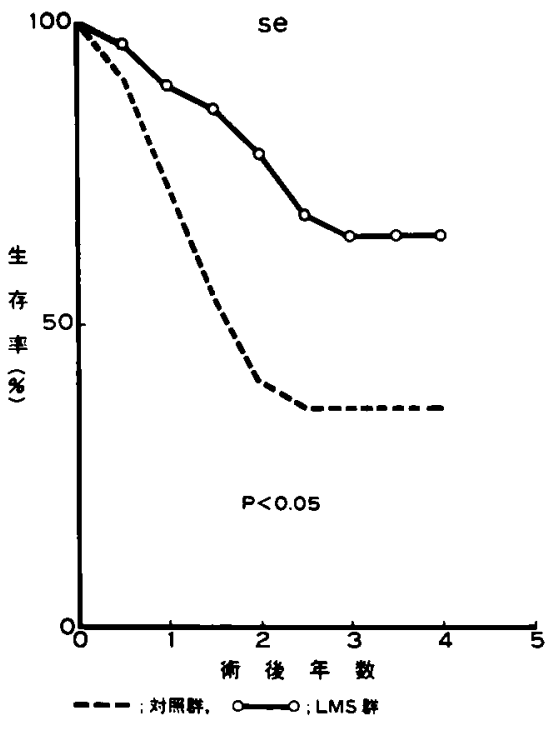

図 6 壁深達度と生存率

裝別では LMS はly, 例に延命効果をむたらした（図 8 ).

\section{考案}

免度賦活鼡等を含む BRM を用いる免疫療法が多く 用いられている。

LMS は免废倵活剛の中でも化学合成品であり, 非 細菌製剤に属する host-mediated に作用する薬郕であ る. LMSの薬効の特徵は，担癌になって細胞性免疫能 が低下した時に，その下った細胞性免疫能を正常に戻 そうと働くことであり，正常以上に増強しない，LMS のこのよらな作用はバラィーターを追跡してゆくこと
で容易に証明でき，レクチンを用いたリンパ球幼若化 反応， $\mathrm{T}$-細胞, active- $\mathrm{T}$ 細胞, $\mathrm{IgG} \mathrm{FcR}{ }^{+} \mathrm{T}$-細胞, NK 活性，ADCC 活性等が低下した癌に LMS を投与する とそれらを正常に戻すように働ぐ。また逆にサプ レッサー活性が増強した例には，それを低下，正常化 するよらに働く8).このような機序で LMS は担癌生体 の免没能を高め，抗腫痬効果を導き，延命をもたら す4).

LMS の抗腫瘍効果は host-mediated で癌細胞を強 カにやっつけていく程のものではないので, 化学療法, 放射線療法や手術等と併用して用いる効果が著しくな る.一般的には隀瘍をできるだけ少なくした上で,残っ た溦量の癌細胞を消失させるためにこの薬剂は効果を むたらすのであり，今回の如き治癁切除の後に化学療 法剂と併用したことが良好な結果を招いたといえる。

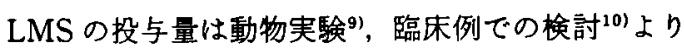
$3 \sim 10 \mathrm{mg} / \mathrm{kg}, 150 \mathrm{mg} /$ day/人/day が至適で，人では $150 \mathrm{mg} / \mathrm{day}$ ，連続 3 日間投与を隔週毎に行っており， それ以上では副作用が強く，少ないと効果がない。投 与開始時期は手術後すぐに細胞性免疫能の低下が生じ るのをLMSを術前より投与しておくとその低下を防 止できるため ${ }^{111212}$, 手術前より投与開始している.今回 の検討でる投与開始は手術 3 日前より行っている。一 方，免疫賦活剤の投与は何時まで続けるべきかは定説 がない，これまでは術後 2 年までが生存率の差が大き く，薬剂効果を見易いことより，術後 2 年までの検討 例が多かったが，生存率がプラトーになるのが術後 3 年であり，胃癌も10年生存率が問題とされる時期に なっているので，今後は術後 3 年位まで薬剤投与を続

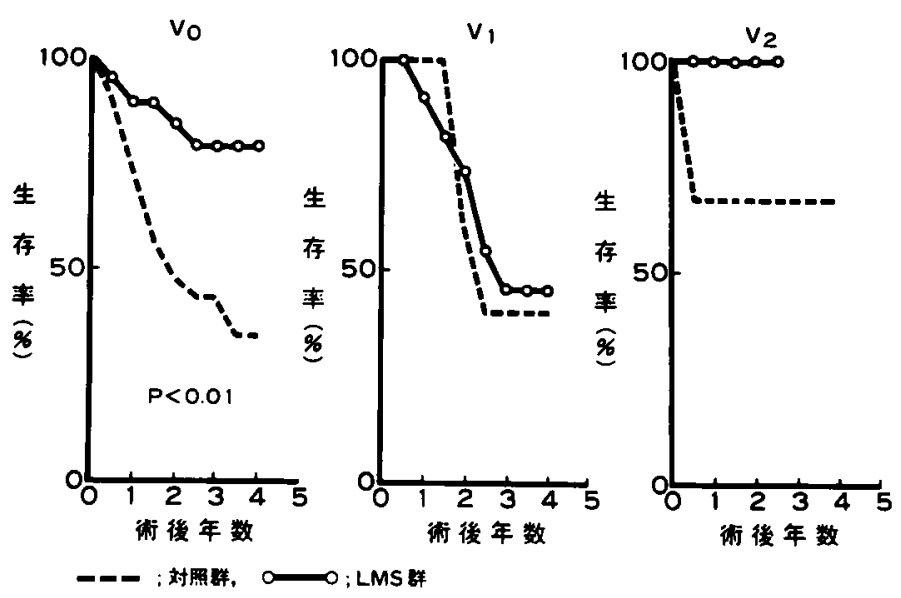

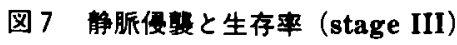




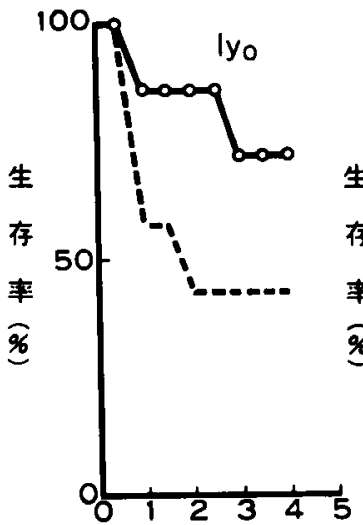

術後年数

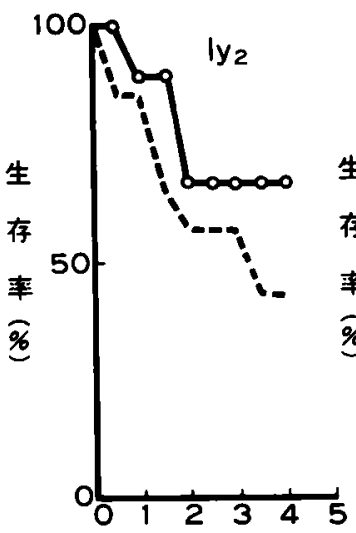

術後年数

-ーー：对昭盽。
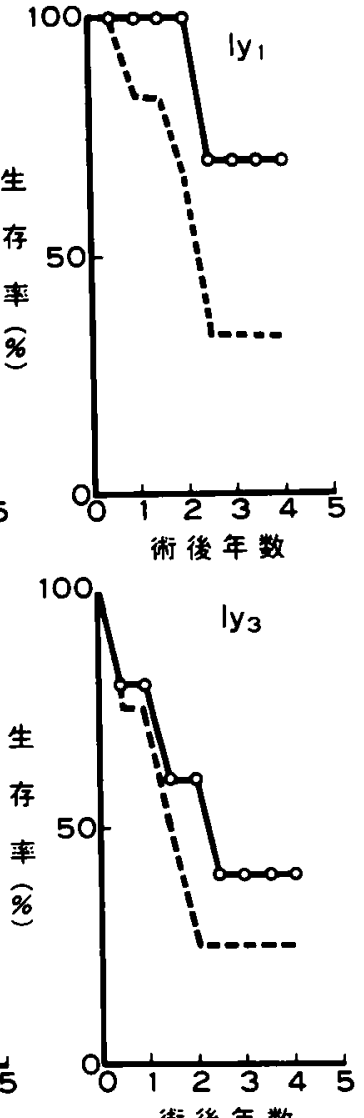

術後年数
術後年数

图 8 リンパ管侵查と生存率（stage III）

けるのがよいい3.

LMS の延命効果を得るための治療対象は, 今回の 検討では胃癌 stage III 例であった. LMSをはじめ, BRM を用いての免疫療法の効果が期待できる治療対 象には，今回の如く，手術のみでほとんど充分な効果 が得られる stage I, stage II や, 遺残腫痬が多いstage IV の症例は入らない. 即ち, 免疫療法のみで治療でき る癌腫は, その癌細胞数が $10^{6}$ 個以下(4)のものである. よって進行癌で, ある程度腫瘍が大きしても治瘦切 除でき，第 1 群リン八節に転移があろらとる通常のリ ンバ節郭清でとり切れ, se と癌細胞が週辺臓器や腹腔 内に払がっておらず， $\mathrm{v}_{0}, \mathrm{ly}_{1}$ と遠隔転移の確率の少な い症例か：LMS を投与すると最も効果のみられる治療 对象となるといら今回の結論となった。

これまでのLMSによる臨床成績は口腔癌でも，肺 癌でも，大腸癌でも，看痬が充分切除しきれる癌例で 良好であっだかか，中には乳癌例で切除不能な症例に
LMS が有意な症例をもたらすとの報告(5)すある。先に 述べた如く，host-mediatedな作用で働く免疫賦活剂 の効果は，主腫場を治してしま5ほど強力なるのでは なく，わずかに残った微小な癌細胞が転移や局所再発 を来すのを防ぐ程度のものと考えてよいと思われる。 LMS 等の最む効果が期待できる症例は，大きな腫㻛 ではあるが，浸潤の強いものではなく，ほとんど完全 に摘出できる癌例 ${ }^{16)}$ である。

主看瘍が摘出できないような末期癌例には，むしろ 腫湯細胞に cytotoxic に働く $\mathrm{BCG}^{171}$ や OK-432 ${ }^{18)}$ 等の 免疫賦活郕を局所投与を主体に用いるのが良い。

\section{結論}

レハミミソールは, 癌腫が中等度の大きさで, リンパ節 転移が $\mathrm{n}_{1}$ と著しくなく、深達度が se と、治㴼妡除ので きた胃癌例に延命をるたらした。

\section{文献}

1) Reymaekers, A.H.M., Allewijin, F.T.N. and Vandenberk, J.: Nobel broad spectrum anthelmintics and related derivatives of 6 -aryl imidazo [2,1-b] thiazole. J. Memd. Chem., $9: 545$ $-551,1966$.

2）三輪恕昭：胃癌の免疫化学療法。癌治療のストラ ティジー一固形癌の補助化学療法一暒谷 鐶監 新興医学出版社, p. 105-184, 1984.

3）三輪恕昭，小野二三雄，小林 努他：免疫化学療法 の進行胃癌 stage III 例への効果, 癌と化療, 9： 1735-1741, 1982.

4）三輪恕昭，折田菜三：免疫賦活剤 Levamisole の 抗腫蕩効果, 臨免疫, 12:491-501，1980。

5）三輪恕昭，折田葶三：免疫倵活剂 Levamisole の 細胞性免疫能賦活効果, 日癌治療会誌，16： 1231-1238， 1901.

6）胃癌研究会編：外科・病理. 胃癌取扱規約, 金原出 版，東京，1979。

7）三輪 楔：進行胃癌の予後について.内科 Mook, No. 8, 金原出版, 東京, p. 312-317， 1979.

8）野上浩美，三输恕昭，日伝晶夫他：MLC suppressor cell に対する levamisole の奻果，医のあゆみ， 118:29-31, 1981.

9) Chirigos, M.A. and Amery, W.K.: Combined levamisole therapy: An overivew of its proctective effects. Immunotherapy of Human Cancer. The University of Texas Cancer System Center, M.D. Anderson Hospital and Tumor Institute. Reven Press, New York, p. 181 
$-195,1978$.

10) Amery, W.K.: Final results of multiccenter placebocontrolled levamisole study of resectable lung cancer. Cancer Treatment Rep., 62 : 1677-1684, 1978.

11) Miwa, H., Kawai, T., Nakahara, H., et al.: Decrease in cell-mediated immunity by surgical intervention and its prevention byy levamisole. int. J. Immunopharmac, $2: 31-36,1980$.

12）南智石，藤本 茂，赤尾建夫他：胃癌治学切除症

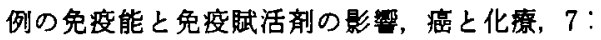
1057-1061， 1980.

13）三輪㤎昭，折田藓三：胃癌手術例への補助免疫化 学㞠法の薏応と方法. 第46回日臨外医会発表，p. 137, 1984.

14) Mathé, G., Florentin, I., Olsson, L., et al.: Pharmacological factors and manipulation of immunity. Systemic adjuvants in cancer therapy. Cancer Treatment Reports. 62 : 1613-1621, 1983.
15) Debois, J.M.: Preliminary experience with levamisole in cancer patients, and particularly in breast cancer. Control of Neoplasia by Modulation of the Immune System. ed. Chirigos, M.A., Raven Press, New York, p. 175-182, 1977.

16) Study Group for Bronchogenic Carcinoma: Immunopotentiation with levamisole in resectable bronchogenic carcinima: A double blind controlled trial. Brit. Med. J., 23: 461 $-464,1975$.

17) Holmes, E.C., Ramming, K.P., Golub, S.H., et al.: Intralesional BCG in pulmonary tumors. Immunotherapy of Human Cancer, ed. Terry, W.D. and Rosenberg, S.A., Elsevier, North Holland, p. 81-86, 1982.

18）三埨恕昭，合地 明，松三 新他：免疫賦活剂胃癌 内投与に上る胃癌組䄉内リンパ球漫润とリンバ節 反応，癌之研，61：2219-2224，1984.

\title{
EFFECT OF IMMUNOCHEMOTHERAPY WITH LEVAMISOLE ON GASTRIC CANCER PATIENTS
}

\author{
Hiroaki MIWA \\ The 1st Department of Surgery, Okayama University Medical School
}

To 84 gastric cancer patients levanisole (LMS) was given starting three days before gastrectomy, at a doses of $150 \mathrm{mg} /$ day for three consecutive days every other week for as long as possible. And the survival rates of LMS group were compared with those of the historical control group. In the stage III gastric cancer patients the back ground factors of the both groups were matched as closely as possible. Both groups were concomitantly treated with mitomycin C and FT-207.

The survival rate of the LMS group was significantly higher than that of the control group ( $p<0.05)$. In the stage III gastric cancer patients the survival rates of the LMS group were significantly higher than those of the control group $(p<0.05)$ when curative resection was performed, the tumor had a diameter of $4.0-8.0 \mathrm{~cm}$, there were metastases within the regional lymph nodes $\left(n_{1}\right)$, cancer cells infiltrated to the gastric serosa (se), cancer cells were not involved in the venous channels $\left(V_{0}\right)$ and they were slightly involved in the lymphatic channels $\left(\mathrm{ly}_{1}\right)$. 